DOI: 10.18276/sip.2017.50/1-09

\title{
Anna Gdakowicz*
}

Ewa Putek-Szeląg**

Uniwersytet Szczeciński

\section{WYMARZONE MIESZKANIE W OCZACH STUDENTÓW - WYNIKI BADANIA ANKIETOWEGO}

\section{Streszczenie}

W artykule przedstawiono wyniki badania ankietowego studentów Wydziału Nauk Ekonomicznych i Zarządzania Uniwersytetu Szczecińskiego na temat ich oczekiwań co do przyszłych nieruchomości mieszkaniowych. Studenci byli pytani, gdzie chcieliby mieszkać oraz jakie czynniki są dla nich ważne przy wyborze nieruchomości mieszkaniowej. Pytania dotyczyły również potencjalnych możliwości finansowania zakupu nieruchomości oraz oczekiwanego wsparcia ze strony państwa. Dane dotyczące preferencji mieszkaniowych uzyskano na podstawie badania kwestionariuszowego (z wykorzystaniem kwestionariusza ankiety) przeprowadzonego wiosną 2017 roku.

Słowa kluczowe: nieruchomość mieszkaniowa, oczekiwania mieszkaniowe, kwestionariusz ankiety

\section{Wprowadzenie}

Rynek nieruchomości mieszkaniowych ma zawsze charakter lokalny, więc jego aktywność (mierzona liczbą transakcji, wysokością cen czy stawek czynszu) uzależniona jest od konkretnych regulacji dotyczących systemu podatkowego, planowania

* Adres e-mail: alatko@wneiz.pl

** Adres e-mail: ewaputek@gmail.com 
przestrzennego i dostępnych fizycznie zasobów gruntu. Jest on szczególnym segmentem rynku nieruchomości - zaliczany jest do najbardziej aktywnych w Polsce. Jednym z czynników determinujących popyt na rynku mieszkaniowym są preferencje potencjalnych nabywców. Przez preferencje klientów najczęściej rozumiane są subiektywne oceny będące podstawą wyborów dokonywanych w procesie zakupu (Czarny, 2006, s. 20). Badania oczekiwań konsumentów przeprowadza się w celu identyfikacji subiektywnych ocen, na podstawie których klient dokonuje wyboru. Umożliwia ona również identyfikację cech produktu, którymi kierują się nabywcy, decydując się na dany zakup.

W rozpoznaniu upodobań można wykorzystać dane historyczne bądź dane o charakterze antycypacyjnym (Trojanek, 2009). Zapatrywania ujawnione są odbiciem rzeczywistych wyborów rynkowych, zaś orientacje deklarowane dotyczą hipotetycznych zachowań nabywców na rynku. W pierwszej z opisanych sytuacji podstawą analizy jest materiał statystyczny dotyczący danych warunkujących wybory rynkowe i przeprowadzone wywiady oraz ankiety (a posteriori). W drugim przypadku w badaniach wykorzystuje się dane zgromadzone a priori, także za pomocą ankiet bądź wywiadów, dotyczące zachowań konsumentów w momencie przeprowadzania ankiety bądź wywiadu (Rybicka, 2003).

Deweloperzy działający na lokalnym rynku nieruchomości zainteresowani są oczekiwaniami potencjalnych klientów co do nowej inwestycji. Grupę potencjalnych klientów tworzą studenci, którzy w perspektywie kilku lat będą aktywnymi uczestnikami (kupującymi, inwestorami, najemcami) rynku nieruchomości mieszkaniowych. Jako ważna grupa graczy rynku nieruchomości studenci byli podmiotem licznych badań (Skotarczak, Nowak, 2010; Urbańska, 2013; Kempa, Krajewska, Palicki, Rącka, Wójta-Kempa, 2015). Artykuł wpisuje się w nurt badań zapatrywań studentów i ich oczekiwań co do nieruchomości mieszkaniowych.

Celem artykułu jest przedstawienie wyników badania ankietowego przeprowadzonego wśród studentów Wydziału Nauk Ekonomicznych i Zarządzania Uniwersytetu Szczecińskiego na temat ich wymarzonej nieruchomości mieszkaniowej. Postawiono hipotezę badawczą: oczekiwania wobec przyszłego mieszkania są różne w zależności od płci, poziomu obecnych dochodów, miejsca pochodzenia (mała czy duża miejscowość) lub aktualnego sposobu finansowania studiów. Zapytano studentów o ich aktualną i planowaną sytuację mieszkaniową. Ankietowani wskazywali, które cechy nieruchomości są dla nich istotne. Studenci mieli też wskazać przewidywane źródło finansowania swojej przyszłej inwestycji mieszkowej oraz odpowiedzieć na pytanie, jakiej pomocy oczekiwaliby ze strony państwa. 


\section{Badanie ankietowe - opis respondentów}

Wiosną 2017 roku przeprowadzono badanie ankietowe wśród studentów Wydziału Nauk Ekonomicznych i Zarządzania Uniwersytetu Szczecińskiego. Formularz ankiety składał się z czternastu pytań oraz metryczki. W ankiecie wykorzystano pytania otwarte, zamknięte (jedno- i wielokrotnego wyboru), półotwarte, warunkowe oraz macierz odpowiedzi. Badanie preferencji mieszkaniowych studentów zostało przeprowadzone metodą wywiadu kwestionariuszowego przy wykorzystaniu ankiety internetowej.

W badaniu udział wzięło 87 studentów studiujących na pięciu kierunkach. Najwięcej osób studiowało kierunki związane z rynkiem nieruchomości: gospodarka nieruchomościami i rynek nieruchomości - 63\%. Kolejną liczną grupę stanowili studenci kierunku finanse i rachunkowość (28,7\%), dalej ekonomiczno-prawnego (4,6\%). Najmniej ankietowanych studiowało ekonomię (3,4\%).

Wśród ankietowanych przeważały kobiety (79\%). Studenci byli w wieku od 20 do 26 lat (najwięcej w wieku 22 lat - 34\%). Blisko 64\% ankietowanych studentów mieszkało w Szczecinie poza rodziną (rys. 1). Najpopularniejszymi formami samodzielnego mieszkania były: wynajem całego mieszkania z innymi osobami (28\%) lub samodzielnie (18\%), mieszkanie w akademiku (8\%), mieszkanie we własnym mieszkaniu (7\%) lub wynajem stancji (3\%).

W grupie osób niemieszkających samodzielnie najwięcej osób mieszkało z rodzicami (23\%) lub codziennie dojeżdżało na zajęcia z pobliskich miejscowości (8\%). Jako przyczyny takiego rozwiązania ankietowani wskazywali, że nie stać ich na zakup samodzielnego mieszkania (17\%), tak jest taniej (12\%) lub wygodniej (6\%). 
Rysunek 1. Rozkład odpowiedzi na pytanie: Gdzie Pan/Pani mieszka w mieście (Szczecinie), w którym Pan/Pani studiuje? (\%)

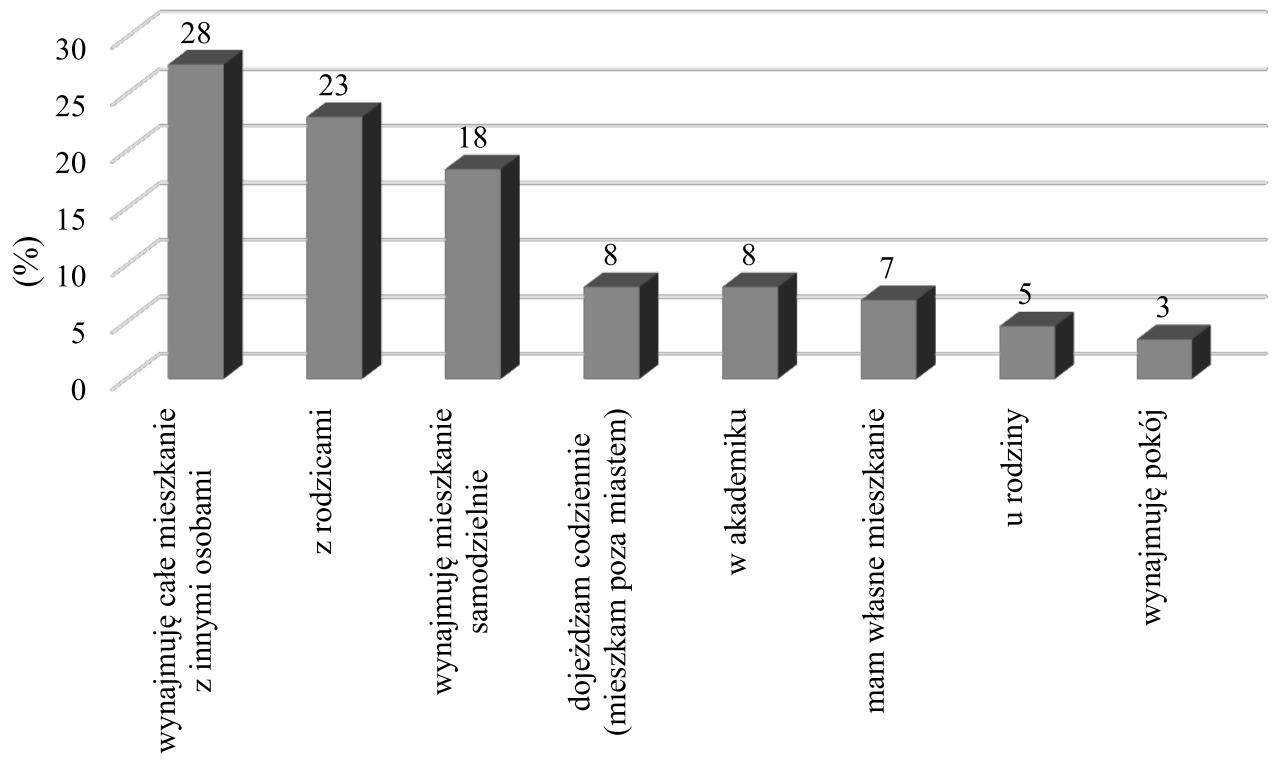

Źródło: opracowanie własne.

Ankietowane osoby mieszkały w dobrych warunkach. W obecnie zajmowanym mieszkaniu studenci mieli do dyspozycji najczęściej $15-20 \mathrm{~m}^{2}$ powierzchni na osobę (46\%) lub więcej (33\%). Poniżej $15 \mathrm{~m}^{2}$ zajmowało 21\% badanych studentów.

Najczęściej respondenci utrzymywali się na studiach dzięki pomocy rodziców (56\%) (rys. 2), z czego dla połowy osób (28\%) było to jedyne źródło dochodu. Pozostali ankietowani uzupełniali środki finansowe otrzymane od rodziców, pracując lub otrzymując stypendium.

Ponad połowa studentów pracowała (56\%). Pracę jako podstawowe źródło utrzymania wskazywało $36 \%$ ankietowanych, przy czym dla $26 \%$ studentów było to jedyne źródło utrzymania, a 10\% korzystało dodatkowo ze stypendiów, alimentów lub renty rodzinnej. 20\% studentów dorywczo podejmowało dodatkową aktywność zawodową.

24\% studentów korzystało ze stypendium, ale tylko dla $6 \%$ był to jedyny dochód. Pozostali bądź dodatkowo pracowali, bądź korzystali z pomocy rodziny. 
Rysunek 2. Źródła utrzymania na studiach (\%; odpowiedzi nie sumują się do $100 \%$ - na pytanie można było udzielić do trzech odpowiedzi)

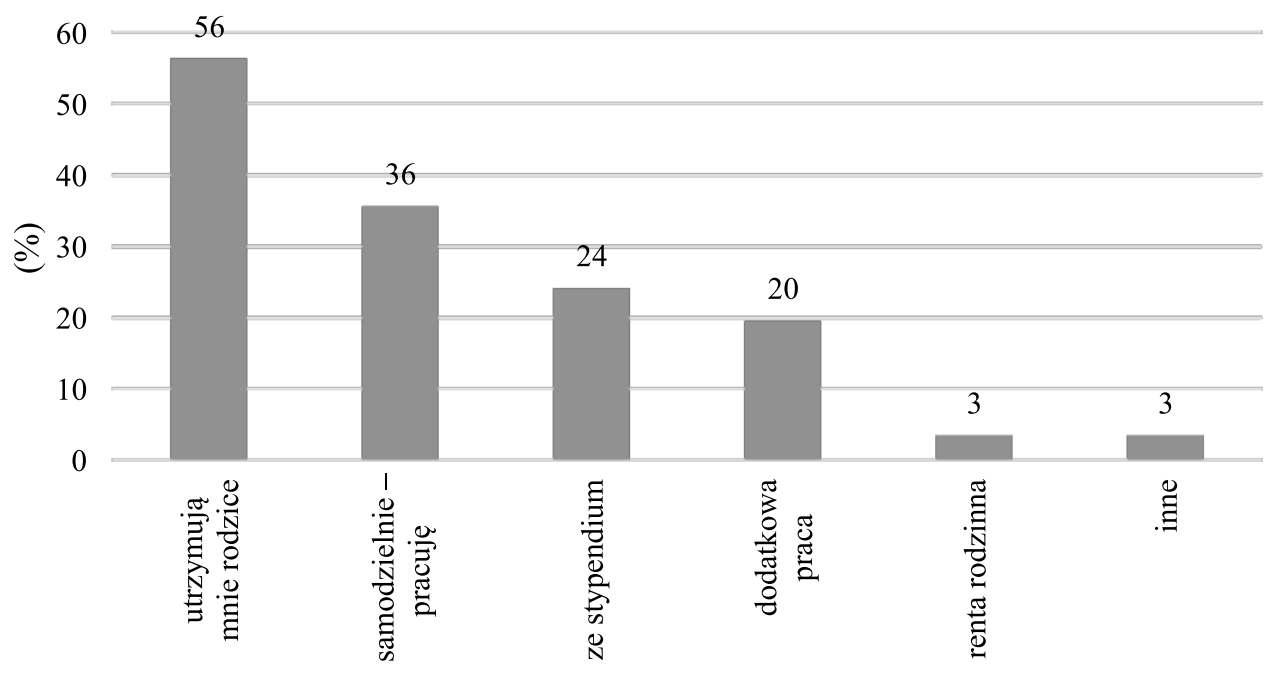

Źródło: opracowanie własne.

$60 \%$ badanych osób utrzymywało się na studiach za kwotę niższą niż $1500 \mathrm{z}^{1}$ (rys. 3). Środkami finansowymi od 1500 do 2000 zł dysponowało 24\% ankietowanych, natomiast 16\% studentów rozporządzało kwotą wyższą niż 2000 zł miesięcznie.

1 Od 1 stycznia 2017 r. minimalna pensja krajowa wynosiła 2000 zł brutto, czyli 1460 zł netto. 
Rysunek 3. Miesięczna kwota, którą ankietowani studenci dysponowali (\%)

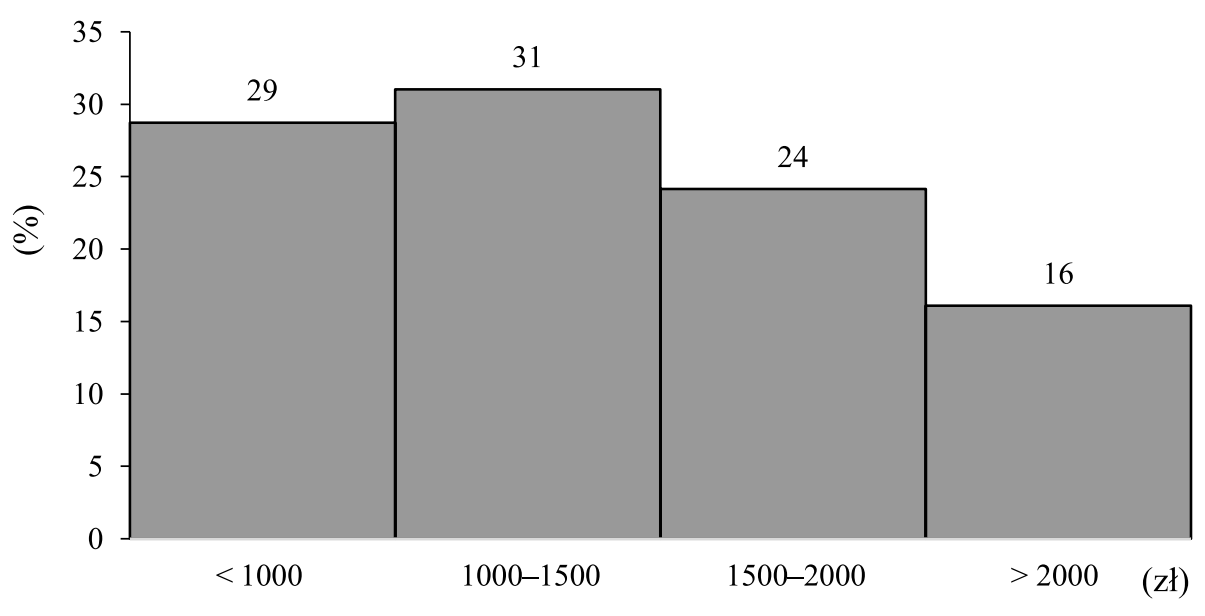

Źródło: opracowanie własne.

\section{Plany mieszkaniowe studentów}

Studenci pytani o to, jakie są ich plany mieszkaniowe, najczęściej wskazywali (rys. 4), że chcieliby wybudować własny dom (51\%) albo kupić mieszkanie na rynku pierwotnym (od dewelopera - 44\%). 24\% osób dopuszczało możliwość wynajmu mieszkania od osób prywatnych, chociaż większość z nich uważała takie rozwiązanie za przejściowe (tylko trzy osoby zaznaczyły wynajmowanie mieszkania od osób prywatnych jako jedyną odpowiedź).

Z oferty sprzedaży lokali mieszkalnych na rynku wtórnym chciałoby skorzystać łącznie 33\% ankietowanych. Połowa z nich preferowała zasób spółdzielni mieszkaniowych, połowa - zasoby wspólnot mieszkaniowych.

$28 \%$ ankietowanych studentów chciałoby być właścicielami domu, ale nie planuje jego samodzielnej budowy - respondenci zamierzają kupić wybudowaną nieruchomość na rynku pierwotnym (14\%) lub rynku wtórnym (14\%).

W badanej grupie uznania nie znalazła oferta towarzystw budownictwa społecznego (TBS) - nikt nie był zainteresowany mieszkaniem w ich zasobach. 
Rysunek 4. Rozkład odpowiedzi na pytanie: Jakie są Pana/Pani plany mieszkaniowe?

(\%; odpowiedzi nie sumują się do $100 \%$ - na pytanie można było udzielić do trzech odpowiedzi)

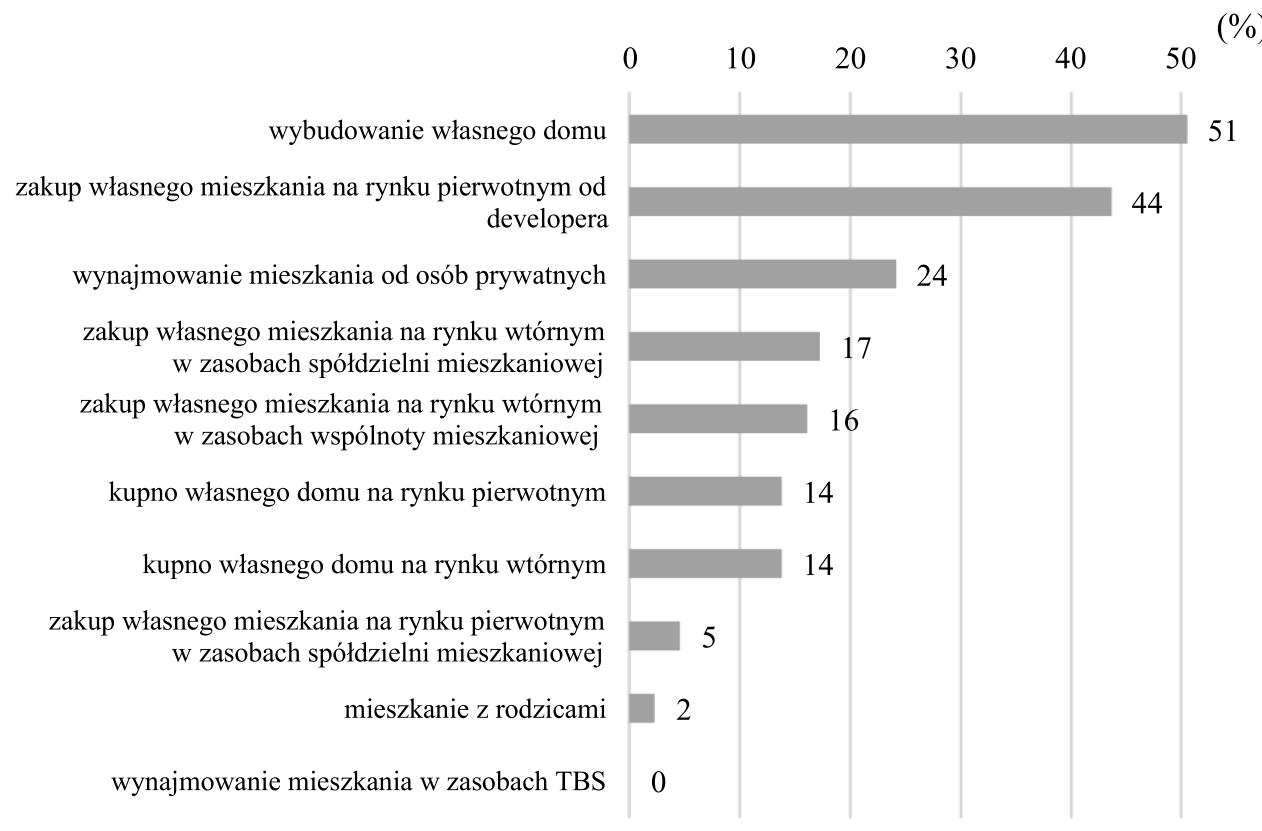

Źródło: opracowanie własne.

Studenci pytani o plany mieszkaniowe mogli zaznaczyć od jednej do trzech odpowiedzi. 47\% osób zaznaczyło tylko jedną odpowiedź, 20\% - dwie odpowiedzi, a 33\% - trzy. Wśród osób zdecydowanych (zaznaczona jedna odpowiedź) dominowała chęć wybudowania domu lub zakupu nowego mieszkania od dewelopera. Przy odpowiedziach wielokrotnych studenci wskazywali albo rozwiązania podobne (np. zakup mieszkania na rynku pierwotnym - zakup mieszkania na rynku wtórnym), albo drogę do osiągnięcia upragnionej nieruchomości (np. wynajem mieszkania wybudowanie domu).

Ankietowani najchętniej chcieliby mieszkać w dużym mieście lub w jego bezpośrednim sąsiedztwie (79\%) (rys. 5). Osób, które chciałyby korzystać z przywilejów dużego miasta, ale niekoniecznie z jego wad (mieszkanie poza centrum), było $37 \%$. W centrum dużych miast mogłoby mieszkać $20 \%$ badanych studentów, natomiast $21 \%$ wybrało tereny podmiejskie. Najmniej pożądaną lokalizacją było centrum małego miasta (3\%). 
Rysunek 5. Rozkład odpowiedzi na pytanie:

Jaka jest Pana/Pani preferowana lokalizacja nieruchomości? (\%)

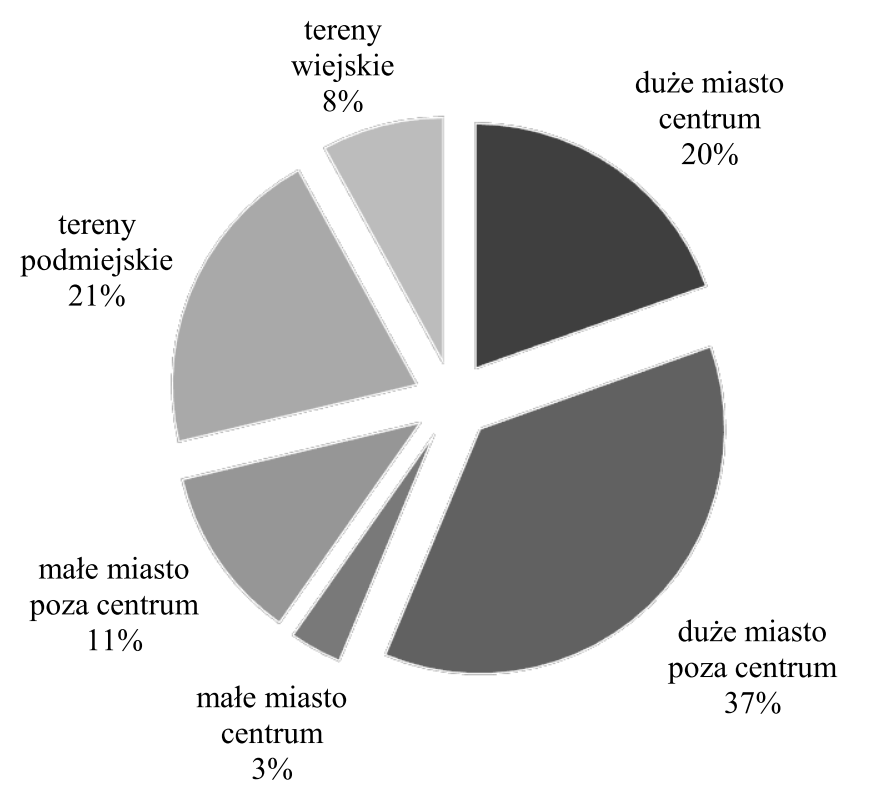

Źródło: opracowanie własne.

W badanej grupie zwolenników mieszkania w lokalach mieszkalnych (mieszkaniach) oraz domach było niemal po równo (z niewielką przewagą na korzyść lokali mieszkalnych) (rys. 6). Najlepiej, gdyby lokal mieszkalny był zlokalizowany w zabudowie niskiej (32\%), chociaż nie musiał to być budynek tylko kilkurodzinny. $11 \%$ studentów nie miało nic przeciwko mieszkaniu w budynku wysokim. Preferujący mieszkanie w domach byli zdecydowanie zwolennikami domów wolnostojących $(38 \%)$.

Kolejne pytania dotyczyły cech, jakimi powinny się charakteryzować wymarzone nieruchomości mieszkaniowe. Osoby, które wskazały w powyższym pytaniu, że chciałyby mieszkać w budynku niskim, wysokim lub kilkurodzinnym, odpowiadały na pytania dotyczące lokali mieszkaniowych (mieszkań), pozostałe osoby - na pytania odnoszące się do domów. 
Rysunek 6. Rozkład odpowiedzi na pytanie:

Gdzie kupiłby/kupiłaby Pan/Pani nieruchomość mieszkaniową? (\%)

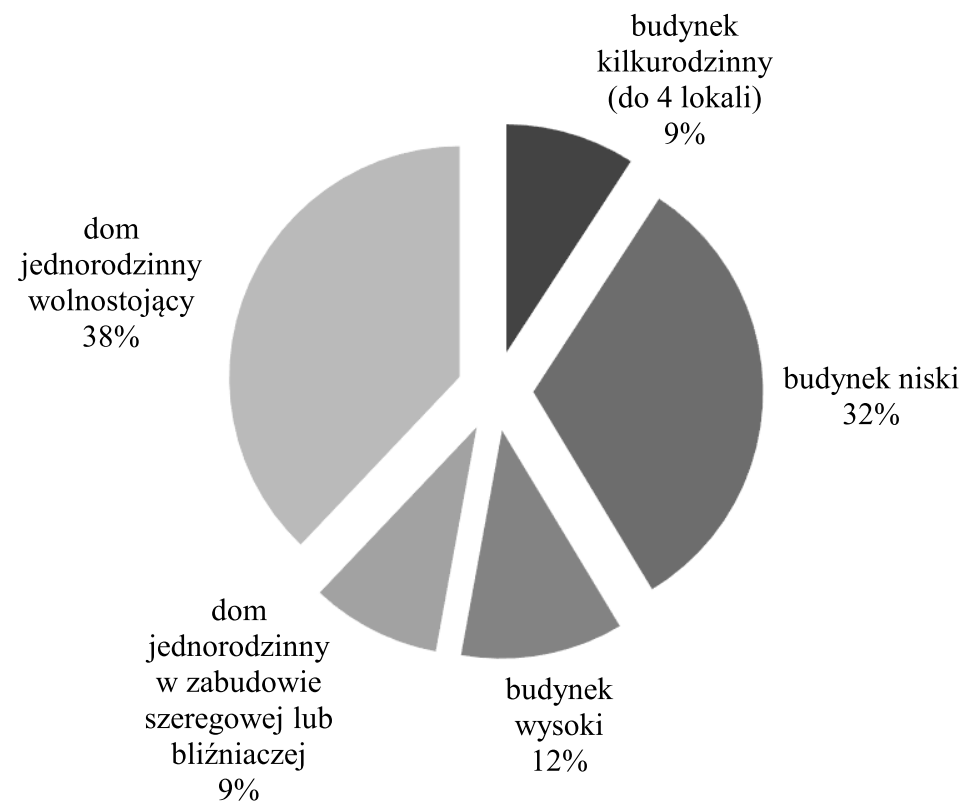

Źródło: opracowanie własne.

\subsection{Lokal mieszkalny}

Preferowane budynki, w których miałyby być zlokalizowane mieszkania, to nowoczesne budynki zbudowane w technologii tradycyjnej (rys. 7). W badanej grupie nie było zwolenników budynków wybudowanych przed II wojną światową (kamienic) oraz z ,wielkiej płyty” (wieżowce wybudowane w latach siedemdziesiątych i osiemdziesiątych XX w.). Dla 1/3 ankietowanych technologia budynku nie miała znaczenia. 
Rysunek 7. Odpowiedzi na pytanie: Wybrana nieruchomość mieszkaniowa byłaby w budynku budowanym według jakiej technologii?

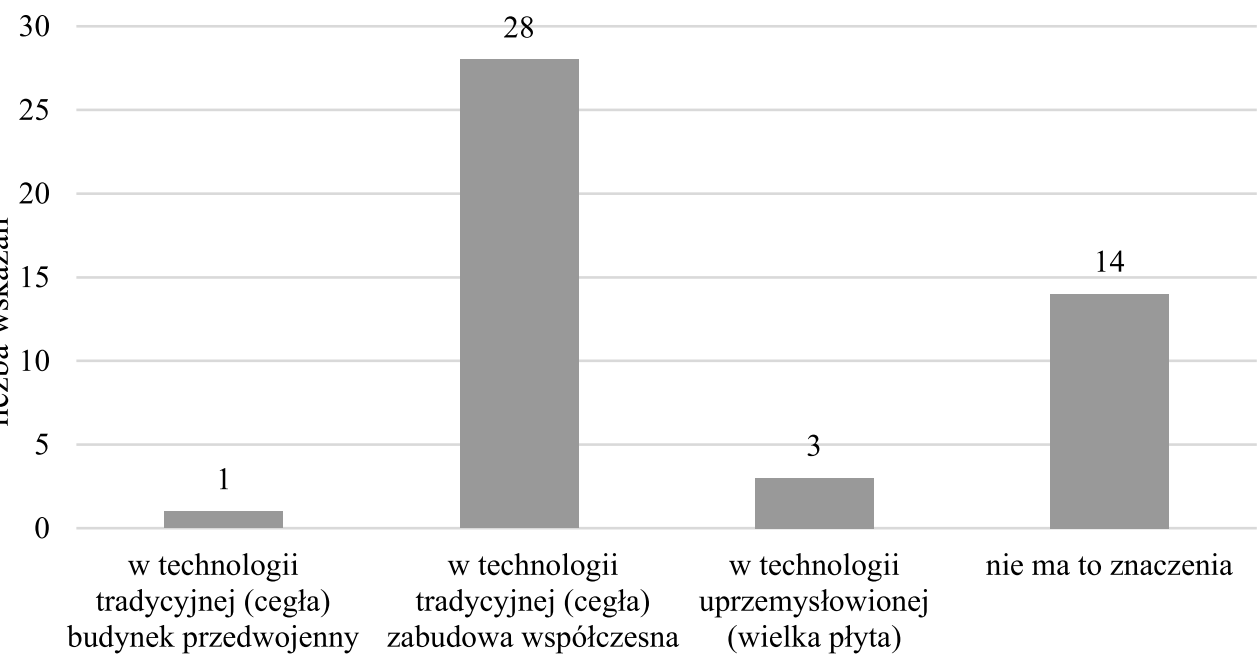

Źródło: opracowanie własne.

Oczekiwania studentów co do wielkości mieszkania były bardzo realne (rys. 8). Ankietowani wskazywali albo na mieszkanie dwupokojowe (50-59 $\mathrm{m}^{2}$ ), albo trzy-, czteropokojowe (70-79 $\left.\mathrm{m}^{2}\right)$.

Rysunek 8. Odpowiedzi na pytanie: Jaka jest preferowana wielkość Pana/Pani mieszkania?

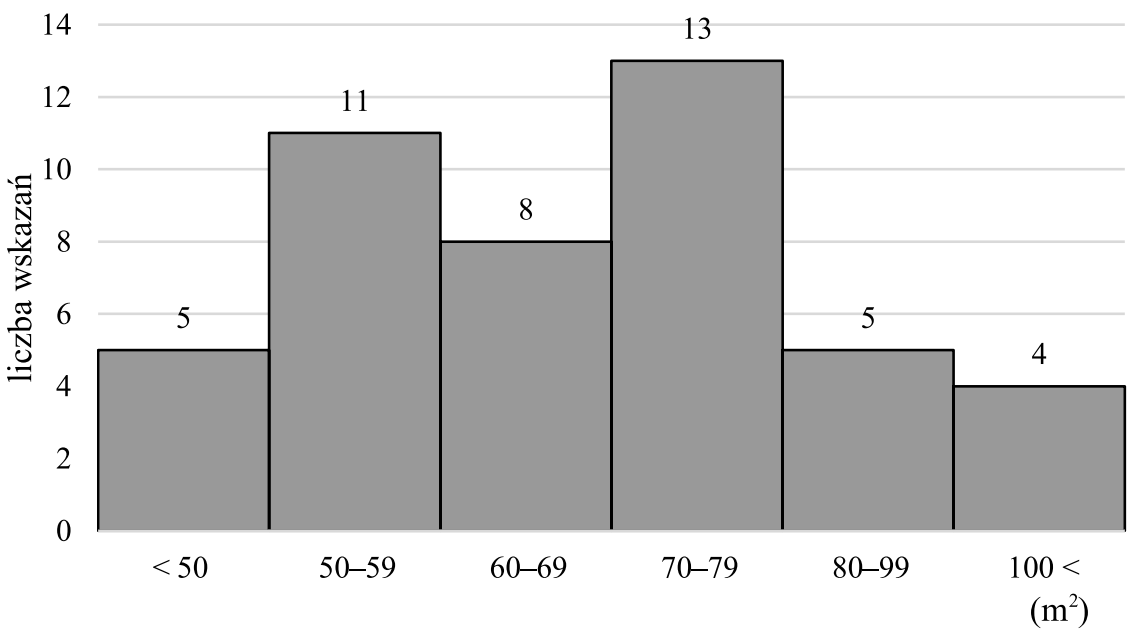

Źródło: opracowanie własne. 
W kolejnym pytaniu ankietowani określali wagę cech opisujących mieszkanie. Wyróżniono trzynaście cech, które należało uszeregować od najważniejszej do najmniej istotnej. Kupując mieszkanie, studenci zwracaliby przede wszystkim uwagę na jego cenę i funkcjonalność (m.in. liczbę pokoi). Następnie dla ankietowanych ważna była powierzchnia i standard mieszkania oraz jego lokalizacja. Kolejna grupa cech - mniej ważnych - to: połączenia komunikacyjne w sąsiedztwie nieruchomości, bezpieczeństwo, technologia wykonania budynku, nasłonecznienie i piętro, na którym znajduje się mieszkanie w budynku. Za najmniej istotne elementy uznano: architekturę budynku, prestiż okolicy, a także sąsiedztwo nieruchomości.

W kolejnym pytaniu respondenci określali, ile skłonni byliby zapłacić za $1 \mathrm{~m}^{2}$ mieszkania. Ceny wahały się od 2000 do 5000 zł. Studenci nie różnicowali ceny $1 \mathrm{~m}^{2}$ ani w zależności od pożądanej powierzchni (rys. 9), ani od lokalizacji nieruchomości (centrum, duże/małe miasto), ani też od rodzaju preferowanego rynku (rynek pierwotny/wtórny).

Rysunek 9. Diagram korelacyjny oczekiwanej ceny $1 \mathrm{~m}^{2}$ i powierzchni mieszkania

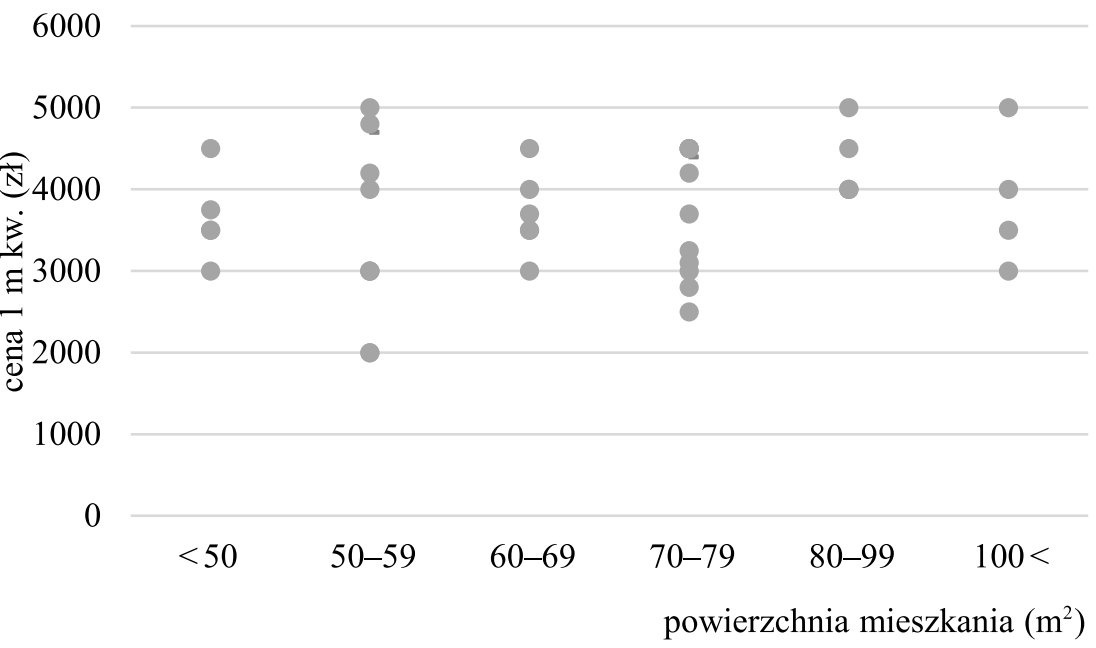

Źródło: opracowanie własne. 


\subsection{Dom jednorodzinny}

Studenci, którzy preferowali mieszkanie w domu jednorodzinnym, odpowiadając na pytanie dotyczące powierzchni domu, najczęściej deklarowali powierzchnię wynoszącą od 100 do $124 \mathrm{~m}^{2}$ (rys. 10).

Rysunek 10. Odpowiedzi na pytanie: Jaka jest preferowana wielkość Pana/Pani domu?

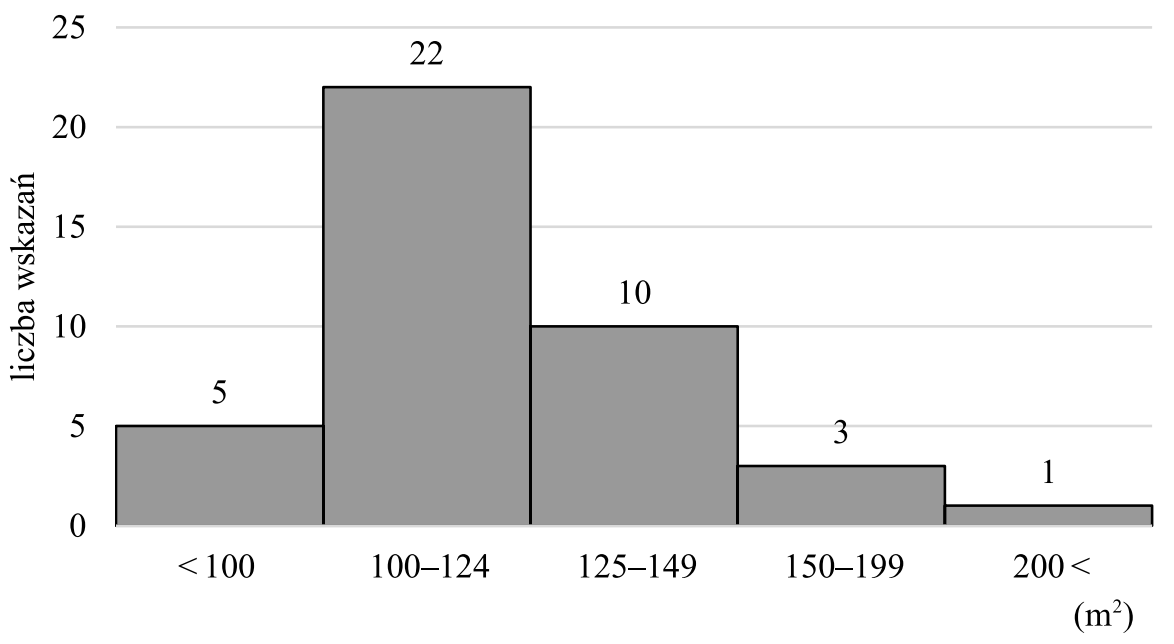

Źródło: opracowanie własne.

Również w przypadku wyboru domu ankietowani poproszeni zostali o określenie wag cech opisujących wybraną nieruchomość mieszkalną. W tym przypadku wyróżniono dwanaście cech (pominięto cechę piętro, która jest nieistotna przy tego rodzaju nieruchomościach), które należało uszeregować od najważniejszej do najmniej istotnej. Studenci, wybierając swój dom, największą wagę przywiązywaliby do prestiżu okolicy, technologii wykonania budynku oraz powierzchni domu. Kolejne cechy to: funkcjonalność, lokalizacja, sąsiedztwo, cena (dopiero na siódmej pozycji!), bezpieczne położenie. Za najmniej istotne elementy uznano: nasłonecznienie, architekturę budynku, połączenia komunikacyjne oraz standard.

Ankietowani zostali poproszeni o wskazanie, jakie środki finansowe byliby w stanie przeznaczyć na zakup wymarzonego domu. Rozpiętość kwot była bardzo duża: od 150 tys. do $2 \mathrm{mln}$ zł (rys. 11). Większość studentów chciałaby przeznaczyć do 600 tys. zł, bez względu na wielkość i lokalizację domu. 
Rysunek 11. Diagram korelacyjny akceptowalnej ceny domu i jego powierzchni

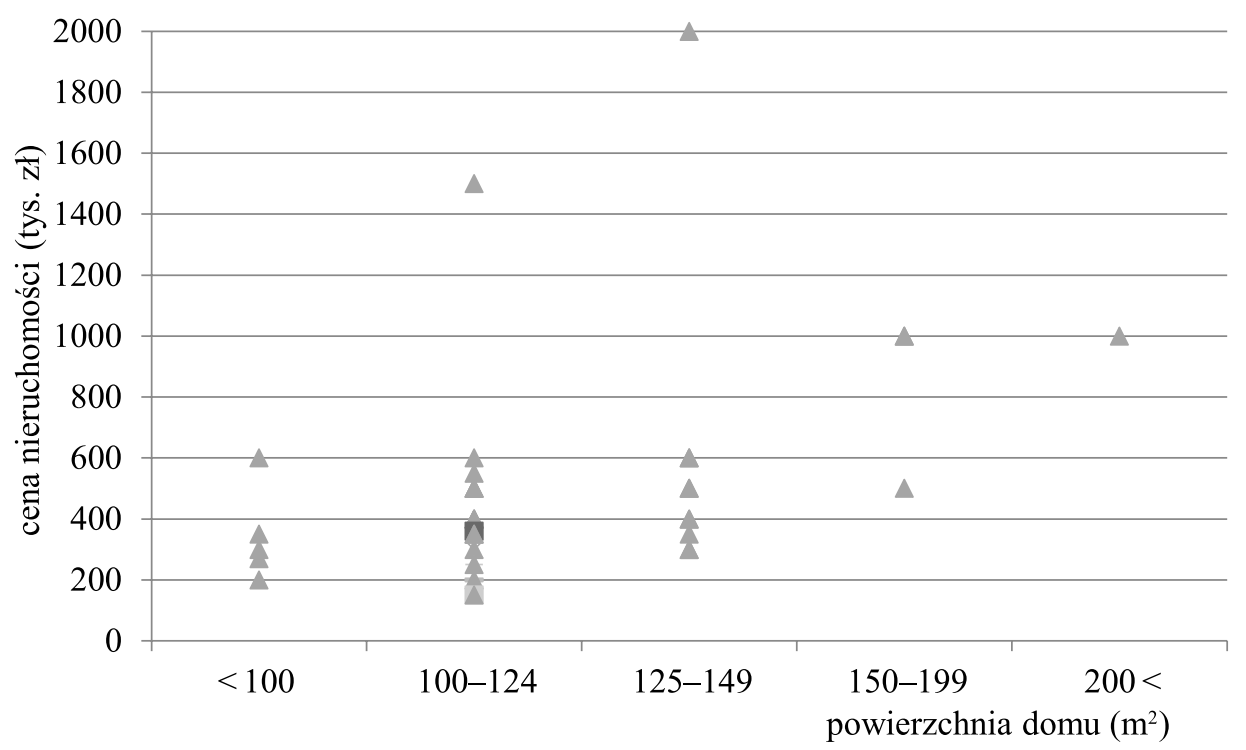

Źródło: opracowanie własne.

\section{Finansowanie inwestycji (wsparcie państwa)}

Zdecydowana większość badanych studentów (87\%) chciałaby sfinansować zakup nieruchomości mieszkaniowej z kredytu hipotecznego (rys. 12). Środki finansowe otrzymane $\mathrm{z}$ banku uzupełnione miałyby być przez dochody $\mathrm{z}$ pracy $\mathrm{w}$ kraju $(62 \%)$ lub za granicą (26\%) albo pozyskane od rodziny (spadek, darowizna, wsparcie rodziców) $-16 \%$.

Pozostałe 13\% studentów jako głównych inwestorów nieruchomości mieszkaniowej wskazuje rodziców albo spodziewa się spadku lub darowizny. Tylko niecałe $6 \%$ ankietowanych planuje zakup nieruchomości z własnych oszczędności, bez wspomagania się zewnętrznymi środkami finansowymi. W tych przypadkach jednak studenci chcą zarobić na własne mieszkanie za granicą. 
Rysunek 12. Jak ankietowani planują sfinansować zakup nieruchomości mieszkaniowej (\%; odpowiedzi nie sumują się do $100 \%$ - na pytanie można było udzielić do trzech odpowiedzi)

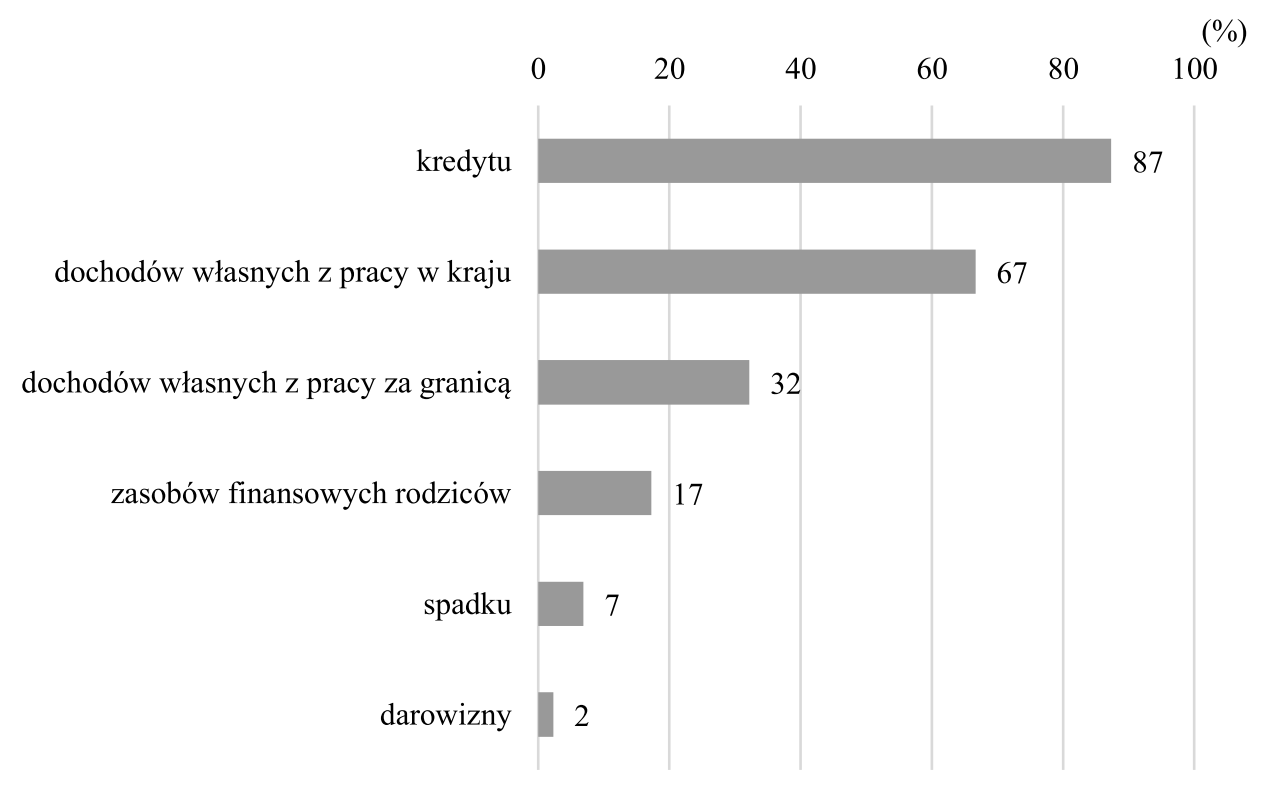

Źródło: opracowanie własne.

Decydując się na kredyt hipoteczny, najwięcej studentów (61\%) chciałoby się zadłużyć od 60 do 100\% wartości nieruchomości ${ }^{2}$. 14\% ankietowanych byłoby skłonnych zaciągnąć kredyt nawet na 100\% (lub powyżej) wartości nieruchomości.

Większość studentów oczekiwałaby wsparcia ze strony państwa w zaspokojeniu swoich potrzeb mieszkaniowych (rys. 13). Dla 63\% ankietowanych pomoc rządu mogłaby się przejawiać możliwością zaciągnięcia kredytu hipotecznego na preferencyjnych warunkach, a dla 7\% - wdrożeniem programu umożliwiającego dostęp do mieszkań na wynajem.

Ostatnie pytanie dotyczyło chęci współpracy przy zakupie nieruchomości mieszkaniowej z pośrednikiem w obrocie nieruchomościami (rys. 14). 33\% badanych studentów zdecydowanych było sobie poradzić samodzielnie, bez wsparcie pośrednika w obrocie nieruchomościami. 7\% respondentów szukałaby nieruchomości miesz-

2 W 2017 r. przy udzielaniu kredytu hipotecznego bank wymagał wpłaty 20\% wartości kredytu w gotówce jako wkładu własnego. Możliwe zatem było zadłużenie nieruchomości maksymalnie do $80 \%$ jej wartości. 
kaniowej, korzystając z pomocy profesjonalistów z biura pośrednictwa $\mathrm{w}$ obrocie nieruchomościami. Większość ankietowanych (60\%) chciałaby znaleźć mieszkanie lub dom samodzielnie (i uniknąć płacenia prowizji pośrednikowi), ale gdyby się to nie udało, jest skłonna skorzystać z usług profesjonalisty.

Rysunek 13. Odpowiedzi na pytanie: Czy oczekuje Pan/Pani wsparcia przy zakupie nieruchomości mieszkaniowej ze strony rządu (i w jakim zakresie)?

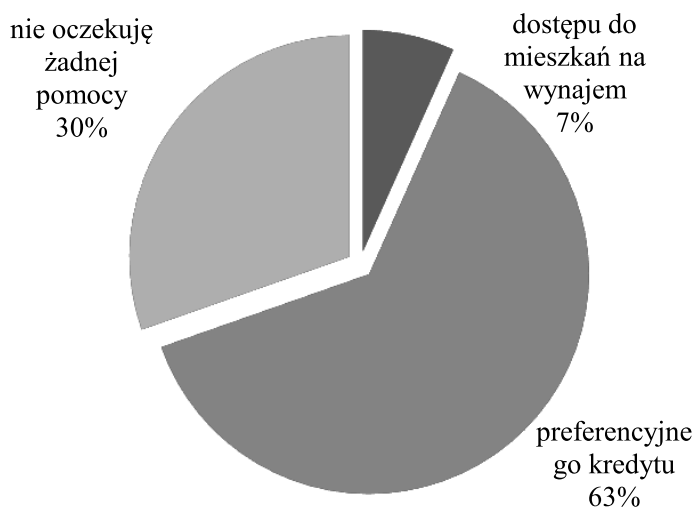

Źródło: opracowanie własne.

Rysunek 14. Odpowiedzi na pytanie: Czy szukając nieruchomości mieszkaniowej do kupienia, zwróciłby/zwróciłaby się Pan/Pani do biura pośrednictwa w obrocie nieruchomościami?

tylko wtedy, gdy po kilku próbach nie znalazłbym zadawalającej oferty sam $60 \%$

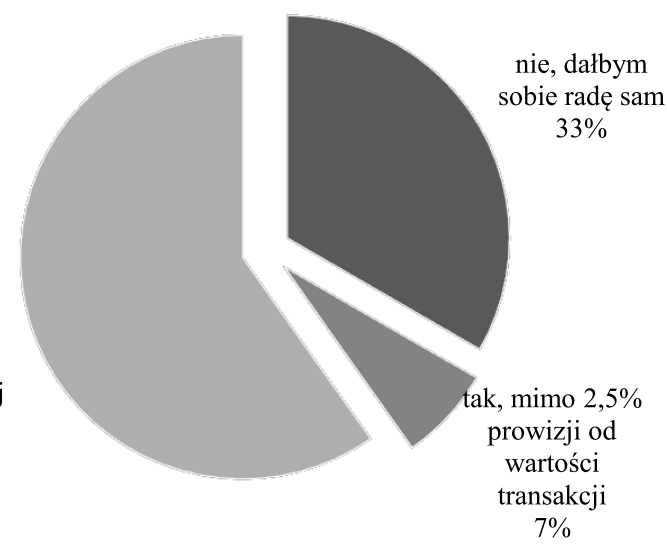

Źródło: opracowanie własne. 


\section{Zależności pomiędzy oczekiwaniami mieszkaniowymi a sytuacją społeczno- -ekonomiczną studentów}

W kolejnym etapie prowadzonej analizy zbadano, czy istnieją zależności pomiędzy udzielanymi odpowiedziami dotyczącymi przyszłych mieszkań a wybranymi czynnikami społeczno-ekonomicznymi. Sprawdzono, czy na preferencje mieszkaniowe ma wpływ płeć ankietowanych, miejscowość, z której pochodzą, obecna powierzchnia mieszkaniowa przypadająca na studenta, poziom obecnych dochodów lub sposób finansowania utrzymania się na studiach. Do zbadania zależności wykorzystano współczynnik zbieżności Czuprowa $T_{x y}$.

Tylko w dwóch analizowanych przypadkach wystąpiła znacząca zależność pomiędzy badanymi zmiennymi. Jedną z nich była zależność między płcią a preferowaną wielkością mieszkania $\left(T_{x y}=0,8\right)$. Panie częściej wykazywały chęć zakupu większego mieszkania niż mężczyźni. W konsekwencji inaczej również zdefiniowane zostały potrzeby wysokości zaciągnięcia kredytu przez mężczyzn i kobiety $\left(T_{x y}=0,85\right)$. Panowie byli bardziej ostrożni i niechętnie zaciągaliby kredyt na $100 \%$ i więcej wartości nieruchomości mieszkaniowej.

\section{Podsumowanie}

Ankietowani studenci byli dobrze zorientowani w panującej na rynku nieruchomości sytuacji. Ich oczekiwania wobec możliwości zakupu nieruchomości mieszkaniowych były wiarygodne i realne. Chcieliby mieszkać w dużym mieście, najchętniej poza centrum.

Studenci będą szukali mieszkań o powierzchni 50-59 lub 70-79 m². Mieszkanie powinno być zlokalizowane w niskim, stosunkowo nowym budynku wybudowanym w technologii tradycyjnej (z cegły). Cena mieszkania nie powinna przekraczać 5 tys. zł za $1 \mathrm{~m}^{2}$, choć lepiej, żeby oscylowała między 3 a 4 tys. zł za $1 \mathrm{~m}^{2}$. Za najważniejszą cechę mieszkania, które chcieliby kupić, uznali cenę i funkcjonalność, za najmniej istotną - prestiż okolicy i sąsiedztwo.

Zwolennicy mieszkania w domu jednorodzinnym myślą o budynku wolnostojącym o powierzchni od 100 do $124 \mathrm{~m}^{2}$. Za taki dom studenci skłonni są zapłacić około 400 tys. zł. Przy wyborze domu będą się kierowali przede wszystkim: prestiżem okolicy oraz technologią wykonania i w małym stopniu będą brali pod uwagę połączenia komunikacyjne i standard. 
Studenci mają świadomość, że aby kupić nieruchomość mieszkaniową, będą musieli zaciągnąć kredyt hipoteczny. Oczekiwaliby, żeby był on udzielony na preferencyjnych warunkach (np. jako program rządowy wspierający zakup nieruchomości mieszkaniowych).

Badane osoby były zorientowane w procedurach związanych z kupnem nieruchomości mieszkaniowej i skłonne były samodzielnie zawrzeć taką transakcję. Jedynie w przypadku przedłużającego się czasu poszukiwań odpowiedniej nieruchomości będą korzystały z usług pośrednika w obrocie nieruchomościami.

Badanie zależności pomiędzy wybranymi zmiennymi wykazało, że kobiety chciałyby w przyszłości mieć większe mieszkanie, a przez to skłonne byłyby zaciągać wyższe kredyty.

Praktyczne wnioski dla deweloperów nieruchomości płynące z przeprowadzonej ankiety to informacja, że studenci są świadomymi uczestnikami rynku nieruchomości, o realnych oczekiwaniach mieszkaniowych. Oferta mieszkaniowa do nich kierowana powinna być funkcjonalna, o nie za dużej powierzchni, w niskim bloku, z lokalizacją w okolicach centrum. Transakcję najlepiej przeprowadzić bez udziału pośrednika w obrocie nieruchomościami, a ofertę większych mieszkań należy kierować do kobiet.

\section{Literatura}

Czarny, E. (2006). Mikroekonomia. Warszawa: PWE.

Kempa, O., Krajewska, M., Palicki, S., Rącka, I., Wójta-Kempa, M. (2015). Students' Preferences on the Residential Real Estate Market in Polish Cities. Real Estate Management and Valuation, 23 (1), 90-102.

Rybicka, A. (2003). Wybrane metody badań preferencji konsumentów. Prace Naukowe AE we Wroctawiu - Zarzadzanie i Marketing, 978, 103-112.

Skotarczak, T., Nowak, M.J. (2010). Preferencje mieszkaniowe kandydatów na studia oraz studentów pierwszego roku akademii rolniczej w Szczecinie. Folia Pomeranae Universitatis Technologiae Stetinensis, Stetin, Oeconomica, 277 (58), 71-80.

Trojanek, M. (2009). Preferencje nabywców na pierwotnym rynku mieszkaniowym w Poznaniu. Acta Scientiarum Polonorum, Administratio Locorum 8 (1), 5-19.

Urbańska, W. (2013). Warunki zamieszkiwania i preferencje mieszkaniowe młodych Polaków w 2007 i 2011. Problemy Rozwoju Miast, I, 143-151. Pobrane z: https://drive. google.com/file/d/0ByN29TQwdbIOTHp2MUwtR1VqbXc/view (5.2017). 


\title{
THE RESIDENTIAL OF STUDENTS'DREAMS - RESULTS OF A SURVEY
}

\begin{abstract}
In the article the authors presented the survey data of the students from the Faculty of Economics and Management University of Szczecin. The survey's aim was to explore students' preferences of residential. The students were asked about where would they prefer to live: in house or in the flat. They had to state which attributes of residential real estate were important to them. The questions concerned the possibility of financing of housing market and what supports are expected from the government.
\end{abstract}

Translated by Anna Gdakowicz

Keywords: dwelling, house, expectation of residential, questionnaire

JEL Codes: R39, C83 